\title{
Village Centre Internal Resources Used for New
}

\section{Development}

\author{
Zuzana Pešková \\ Faculty of Civil Engineering, Czech Technical University in Prague, Prague 16629, Czech Republic
}

\begin{abstract}
Villages historically have been founded around agriculture but farm land has greatly changed, mainly in the areas of the centralised conception of agriculture from the 1950s. Original parcelling, homestead composition and functional layouts have stopped being useful for current village inhabitants. The Czech Republic is an example of an area where this problem has appeared. According to the Czech Statistical Office, the number of inhabitants working in agriculture is now only $1 \%$. Therefore, we need to concentrate on the village historic centre: the possibilities of restructuring and the definition of its potential and possibilities for new development. The internal resources of the village mentioned in this paper refer to the buildings, structures and land of the village centre core. The case studies worked out by the students of architecture in the Faculty of Civil Engineering of Czech Technical University in Prague from the 1990s were used for the research. Comparing designs can define these basic approaches to the new historic centre's use: a spatial solution - urban (non-invasive and invasive) and architectonical (reconstruction, traditional form with modern detail or completely modern design) and a functional solution. The research shown in the original historic village core offers enough opportunities for new usages and non-agricultural functions which are suitable for this area.
\end{abstract}

Key words: Village, rural architecture, rural-urban planning, rustic farms, conversion.

\section{Introduction}

The rebuilding of rural areas is a long-debated issue $[2,3,8-10]$, especially in the Czech and Slovak Republics where the continuous development of villages was interrupted by changes during the communist era (1948-1989). Moreover currently, it begins to reflect the recent trend in energy management [1]. The effectiveness of different types of urban development examined shows that the historical form still appears to be very convenient. The reason is simple: our ancestors handled heat very carefully mainly because heat had to be self-catering [11]. The historic core of the village, which is now going through a usability crisis, restricts the potential development of the village in its current layout.

The historical urban centre structure of Czech villages was based on the close relationship between man and farmland. From the 19th century, this

Corresponding author: Zuzana Pešková, Ph.D., research fields: architecture and urbanism (especially rural space). E-mail: zuzana.peskova@fsv.cvut.cz. relationship began to unravel. Society has changed and its needs as well. All this culminated, especially in the second half of the 20th century when the influence of socio-political changed and unstoppable technological progress led to the abandonment of the traditional way of farming. The natural consequence of this process has been a long-term rural population lifestyle change. While a hundred years ago, most villagers earned a living by agriculture. Today the focus has shifted to a livelihood in the service sector. This is also reflected in housing. Deep, elongated parcels that met the needs of the medieval feudal society have lost reason in the modern rural urban structure. This is not a historically new phenomenon. In the Middle Ages, homes were often built at the cost of the previously older village which had been abandoned to create a new extension of the village. This was allowed thanks to the then large land reserves. The displacement of villages was a relatively frequent phenomenon. Today, the Czech settlement structure is dense enough (the average distance between two 
villages is $1.5-2$ miles) so that the idea of mass abandonment of current villages and building new villages to new locations is completely utopian. The logical solution has been the emergence of suburbs. New housing that meets the present needs of people is expanding beyond the historic core of the originally agrarian villages. This modern trend breaks the direct relationship between farms and farmland and voraciously occupies more and more parts of the arable land. It also blurs the transition element of green orchards and gardens between the village and the open landscape. This phenomenon is not just a Czech problem. It occurs throughout Europe in villages that were based on the needs of the feudal land order. This creates a configuration of the core of the village being abandoned and the population moving into modern houses in marginal areas outside the core, but often with no ties to any services, which need to be supplied from the nearby village.

Recent research is concerned with the possibility of even redefining parcels on the basis of the energy needs of the population [1]. In essence, this is an analogy to the Middle Ages processes transformed to the current priorities of humanity. While medieval village parcels were designed in regard to yield capacity, current parcels should be designed and built with respect to their energy efficiency. Conversion of the historic core of the village and the prevention of further expansion of buildings into the countryside are the first step to maintaining energy efficiency of the whole urban system.

The gradual abandonment of unsatisfactory arrangements inside the historical village centre is currently a hot topic. As early as the 1950s, the options of rebuilding rural settlements were researched [2]. In the 1970s, the team of authors (Vodera and Skabrada) defined how it was possible to use the historic core of the village for new features and how to repair and modify rural buildings [3]. At the Faculty of Civil Engineering of the Czech Technical University in Prague, the issue has been extensively studied (both theoretically and practically), especially the architectural studio projects led by professor Sykora, associate professor Kosatka and architect Mrs. Knappova who address these rural issues. The Faculty of Civil Engineering participated in buildings for rural areas [4] and the competition of rural ways. Even today, the issue of rural areas is taught to students. On the basis of design, the basic theoretical resources can be summarized in dealing with village historic centre [5].

\section{Village Historic Centre as a Potential for Further Development}

\subsection{Spatial Solution}

\subsubsection{The Urban Answer}

A non-invasive solution involves leaving the land allotment and historic urban structure in its current state. Vacant lots, ruins and demolished structures are identified during the processing of urban planning documentation on their parcels so that they can be designated as new functional plots. Regulations then outline the character of the new buildings. Defined stages can clarify which will be the first sections developed and after what may be extended to the current level of the built-up area of the village centre. Basically, it is a solution of minimum intervention, which does not respond to the need for changes to the existing urban structure of the village and does not offer to greatly exploit the potential of the historical village centre. In terms of property relations, the minimum intervention proposal is a straightforward method that can be applied in the preparation of urban plans relatively smoothly.

The invasive solution constitutes of interfering in the surviving historical land allotment.

It can be divided into two possible approaches:

(1) The original gothic land allotment is divided crosswise into two or three smaller parcels, which are operated either from the existing behind-threshing floor path or by newly constructed service roads that divide the plots transversely [3]. This solution can be observed by the width module of original parcels and in 
the total land allotment module depth. Buildings towards the central area can be maintained (Fig. 1). The original farm buildings are either replaced by a new building or they can be adapted to a new function within the housing on the second to third plot. This solution is, after all, common in the countryside, "the young build their house in the garden". The main problem of this solution is land ownership. The owner of land has to agree with the division of his parcel. The division between members of one family was historically very common and the owners were officially called according to the size of their land. For example, in the nearby regional town of Rakovnik, this solution is very frequent, not in the whole conception of the village, but in individual parcels. The average size of the original plot in this area are 36 yards in width and 164 yards in depth. So the division into three parts offers three luxury contemporary parcels for family houses. The density of buildings and population naturally rises two or three times according to the number of new parcels;

(2) The farmhouse is treated as a whole. Individual objects are adapted to new functions. The inner

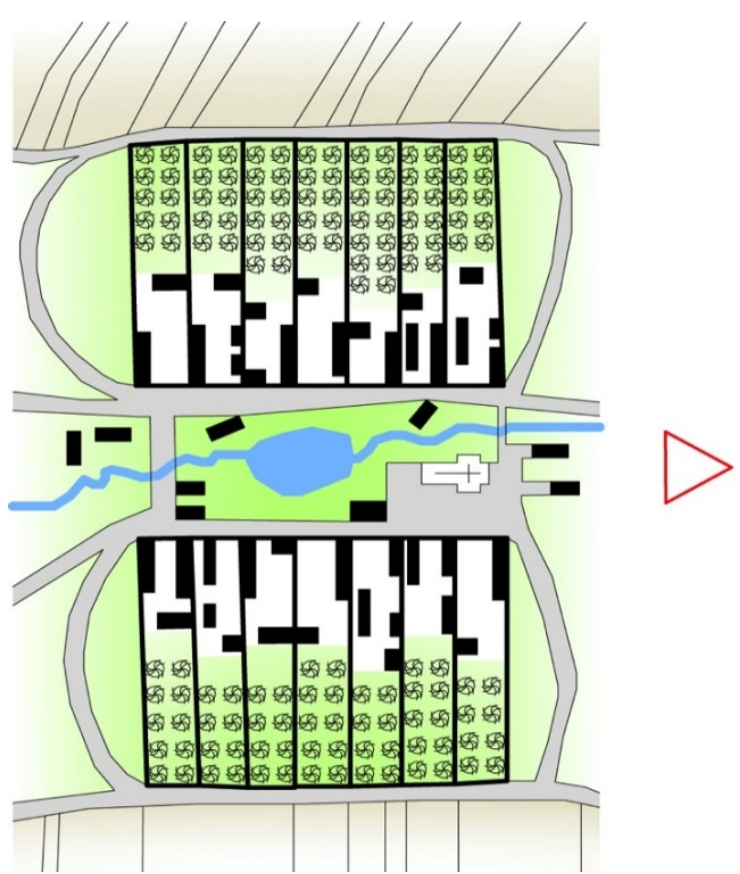

(a) courtyard can be used as a semi-public space, connected with an adjoining garden and orchard behind the barn. This arrangement can be used for both functions in public and small-scale production, as well as housing. This newly restores the principle of the non-effective manor farmhouses reformation by F.A. Raab used in 18th century in the Habsburg Empire, with which we can create interesting community housing by using proper segregation. Splitting large parcels into smaller sections that sub-users can manage should always allow for re-interpreting the original land allotment (Fig. 2).

\subsubsection{Architectural Answer}

Reconstruction of an historical building is often a very expensive method, which never brings such comfort to the user as a new building. On the other hand, there are factors that balance all the rational arguments: the genius loci, the character of the historic buildings and structures, life events that occurred in the building - something difficult to describe exactly, but are very well perceived. The refurbishment of old houses can provide very high comfort to the users as many examples have already shown (Figs. 3-7). One

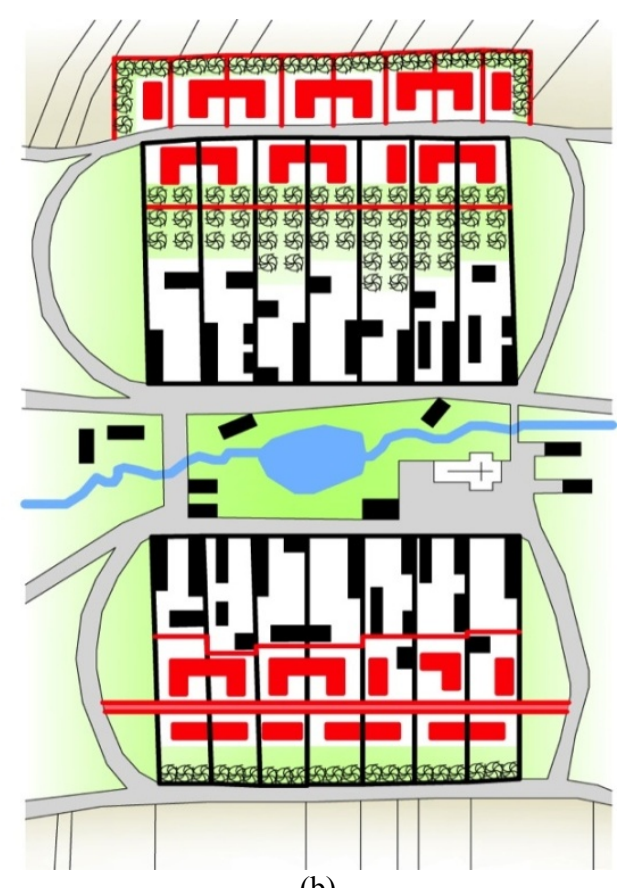

(b)

Fig. 1 (a) The original village; (b) two opportunities to place new buildings to preserve traces of the original land allotment of the historic village center (sketch by author). 


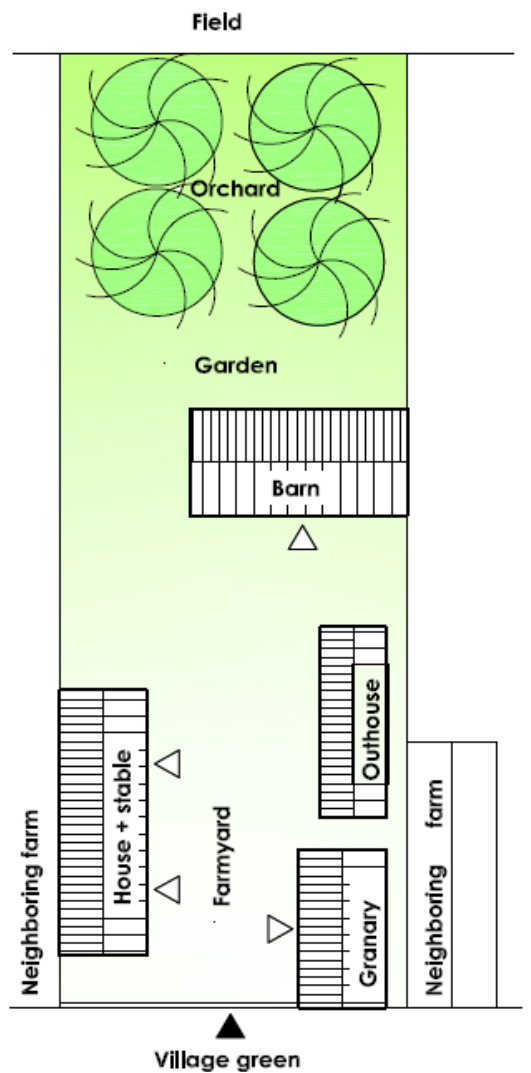

(a)

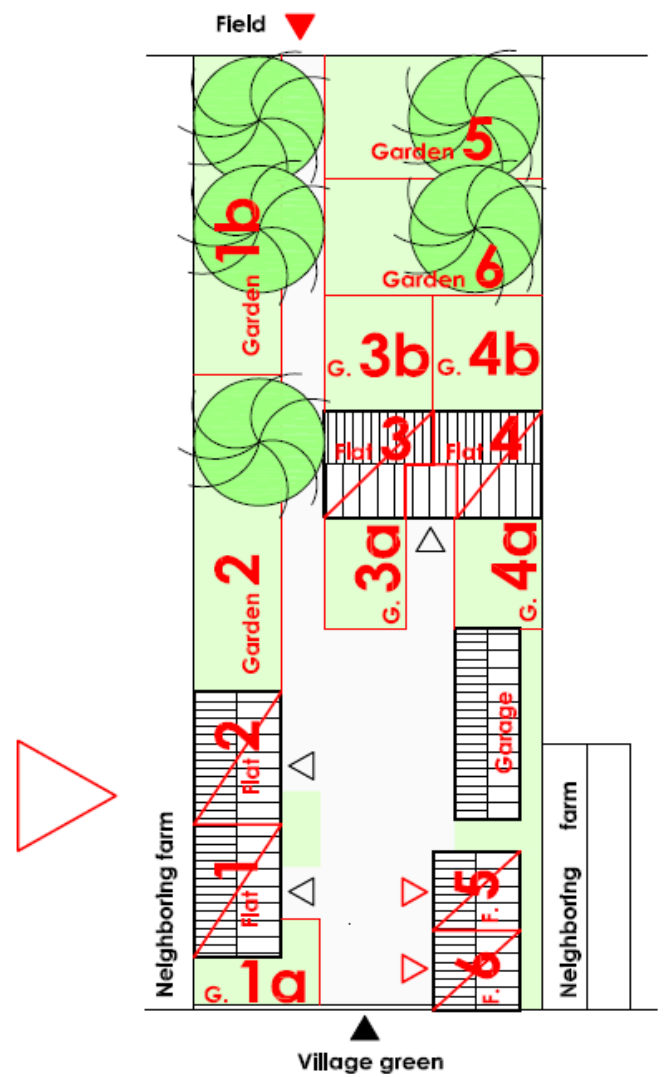

(b)

Fig. 2 (a) The original farm; (b) an example of an adaptation of the buildings to a new function, including the redistribution of the plot (sketch by author).

interesting potential in the reconstruction features of the original farm objects, especially barns and sheds with this free disposition and large span roof, can adeptly meet more needs of modern people than the traditional rural dwelling [3].

When dealing with a new building again, there are two possible methods: either respect the traditional aspect of the surrounding buildings and use contemporary detail or use a rural environment modern design.

Traditional volume and modern detail (Fig. 8) showed that our ancestors were very economical with heat. The development of rural housing is essentially the development of the heating method. As was shown in a unique project for the construction of passive houses in Koberovy, a rectangular ground plan with a saddle roof in terms of house volume is a very suitable energy design [6]. The choice of using traditional folk architecture shapes is, therefore, a safe way to design a new object in a given locality in the context of the surrounding buildings and also meets current requirements. Professor Skabrada defined 10 rules of etiquette for new buildings in the Czech countryside which respect the traditional volumetric design of buildings [7]. The reason is to prevent excessive modern design in villages, preserve historical areas, avoid damage and preserve the distinctive character of Czech villages for future generations.

\subsection{Modern Design}

Using modern design is always an individual matter and very sensitive. Unfortunately, Czech villages have had some negative experience with this architectural approach from the days of the socialist construction village. Not all designers are able to deal with the task, but if successful, it can enrich rural areas. A suitable approach can be considered as an architectural design that works with the landscape (Fig. 9) so that it 


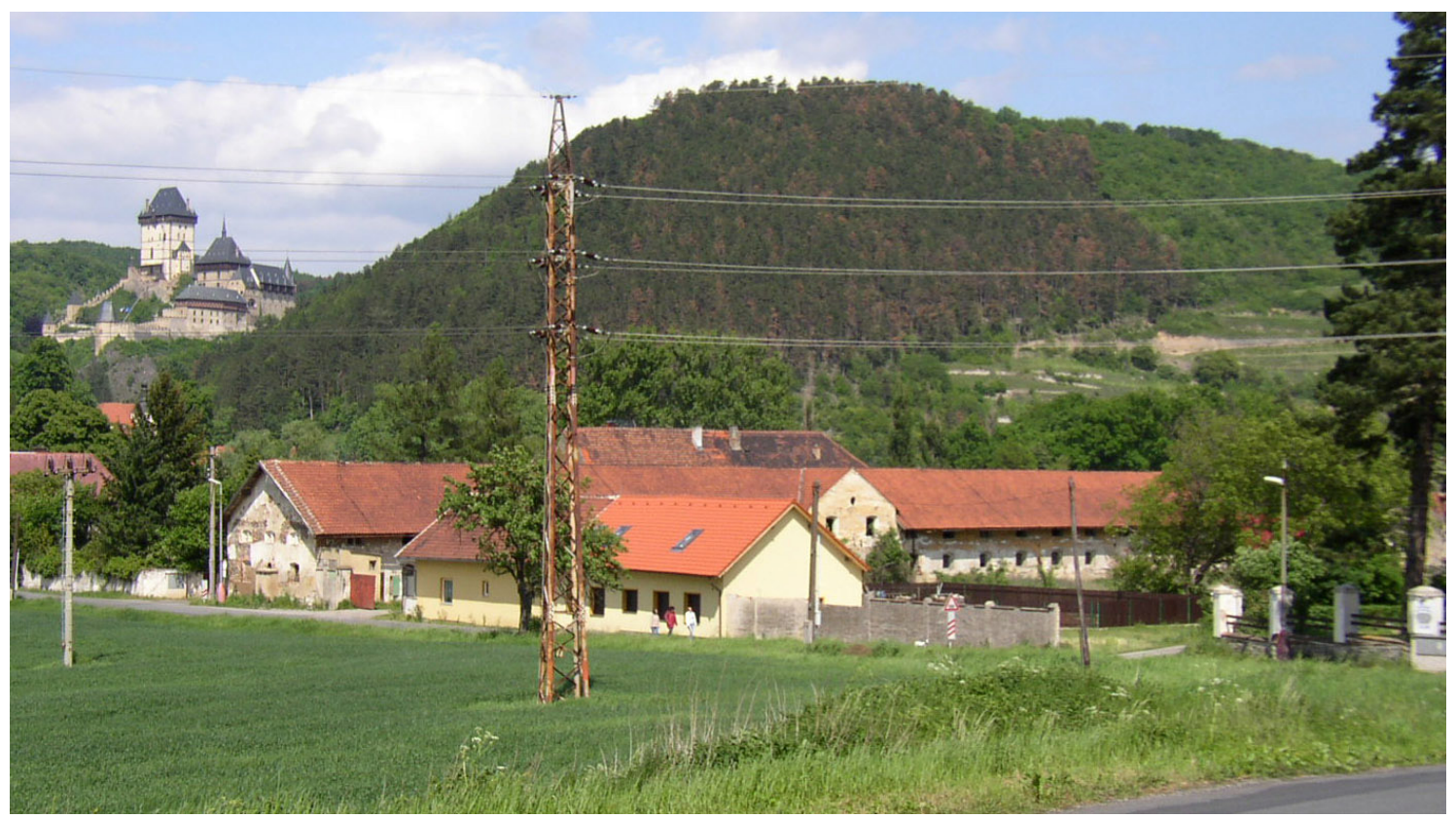

Fig. 3 Large farm in Karlstejn in original condition, 2004 (photo by author).

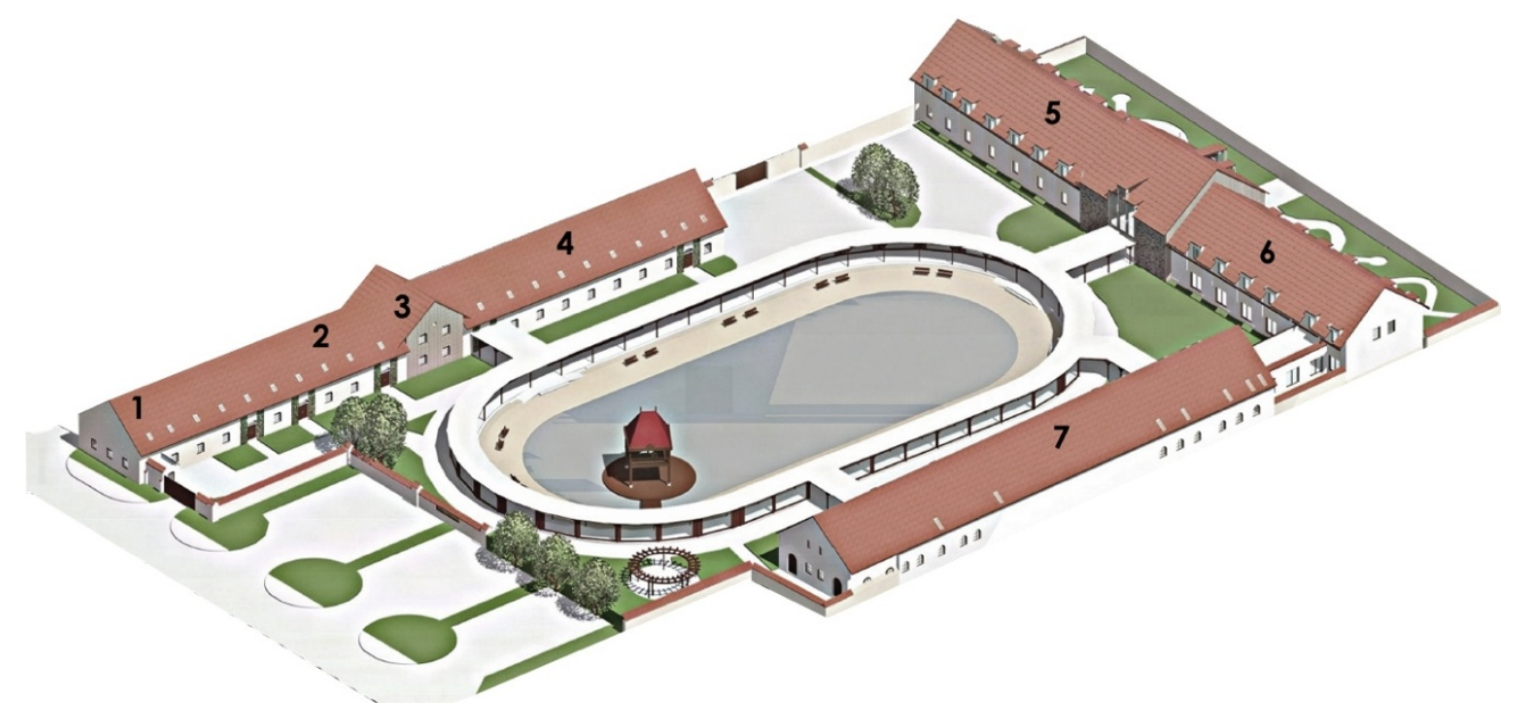

Fig. 4 Conversion of the farm in Karlstejn: 1-4 are gatehouse and a caretaker's apartment, fitness, entrance hall, restaurant and upstairs guest rooms (originally a stable), 5-6 are guest rooms, a small conference room and upstairs guest rooms (originally a barn), 7 is a large conference room (originally a shed). They are designed by Z. Peskova and supervised by $J$. Sykora, 2004.

completes the existing construction. In essence, the new building is hidden in the terrain modelling and the green roof creates a base of the historical village pyramidal composition. Architecture that uses various inclined planes is acceptable (Fig. 10). For example, the usage of just pure cubes for individual family house design is not a good solution in the context of the surrounding buildings with saddle roofs typical for a traditional Czech village. There are many negative examples. Even so, in part of a new group of building design, a cube shape structure could be very inspiring as many examples have already shown.

\subsection{Functional Solution}

Mixed functions of agricultural, residential, manufacturing and civic facilities were all situated in 


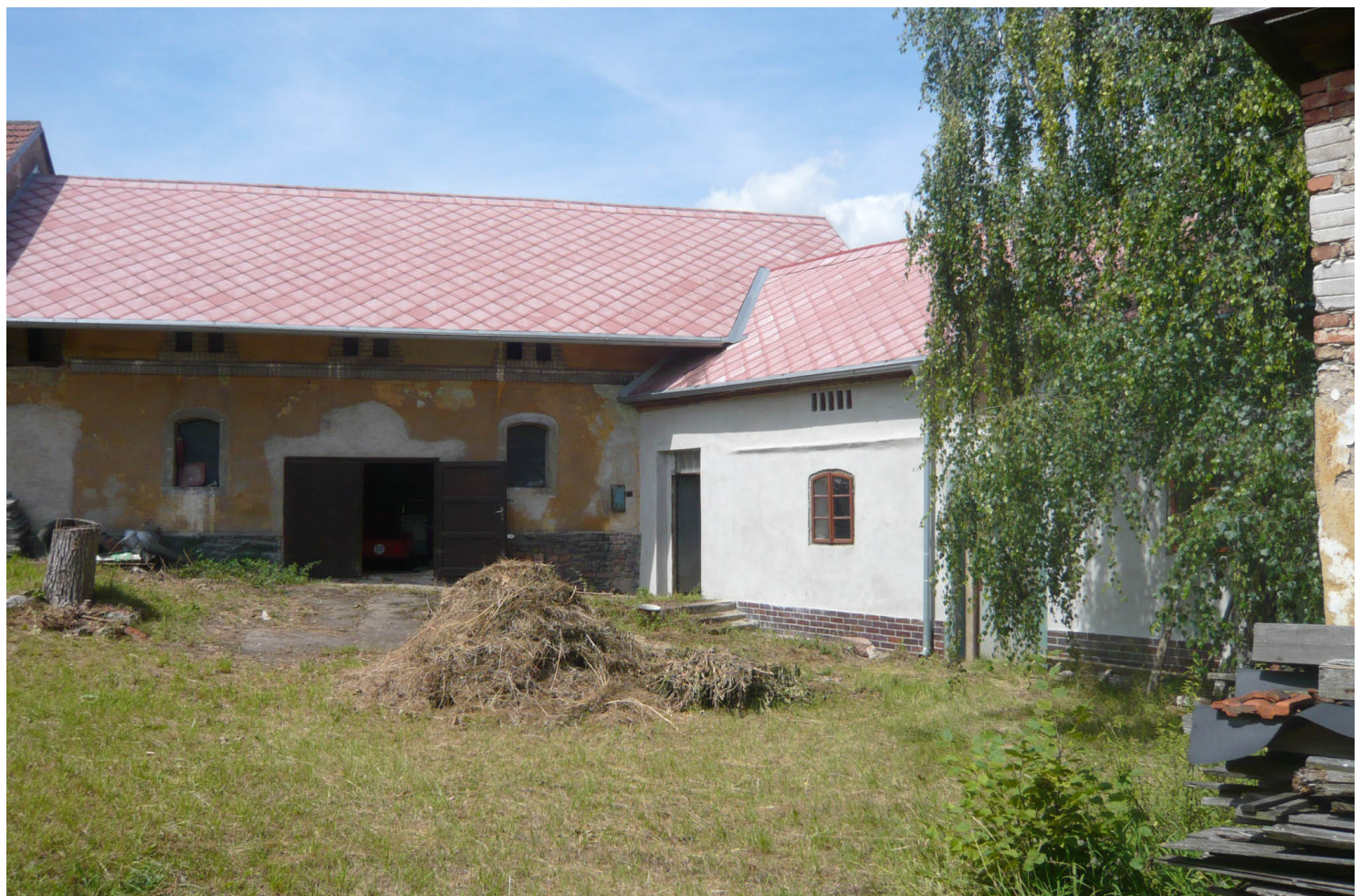

Fig. 5 Farm in Koneprusyin original condition of the farm buildings, 2009 (photo by author).

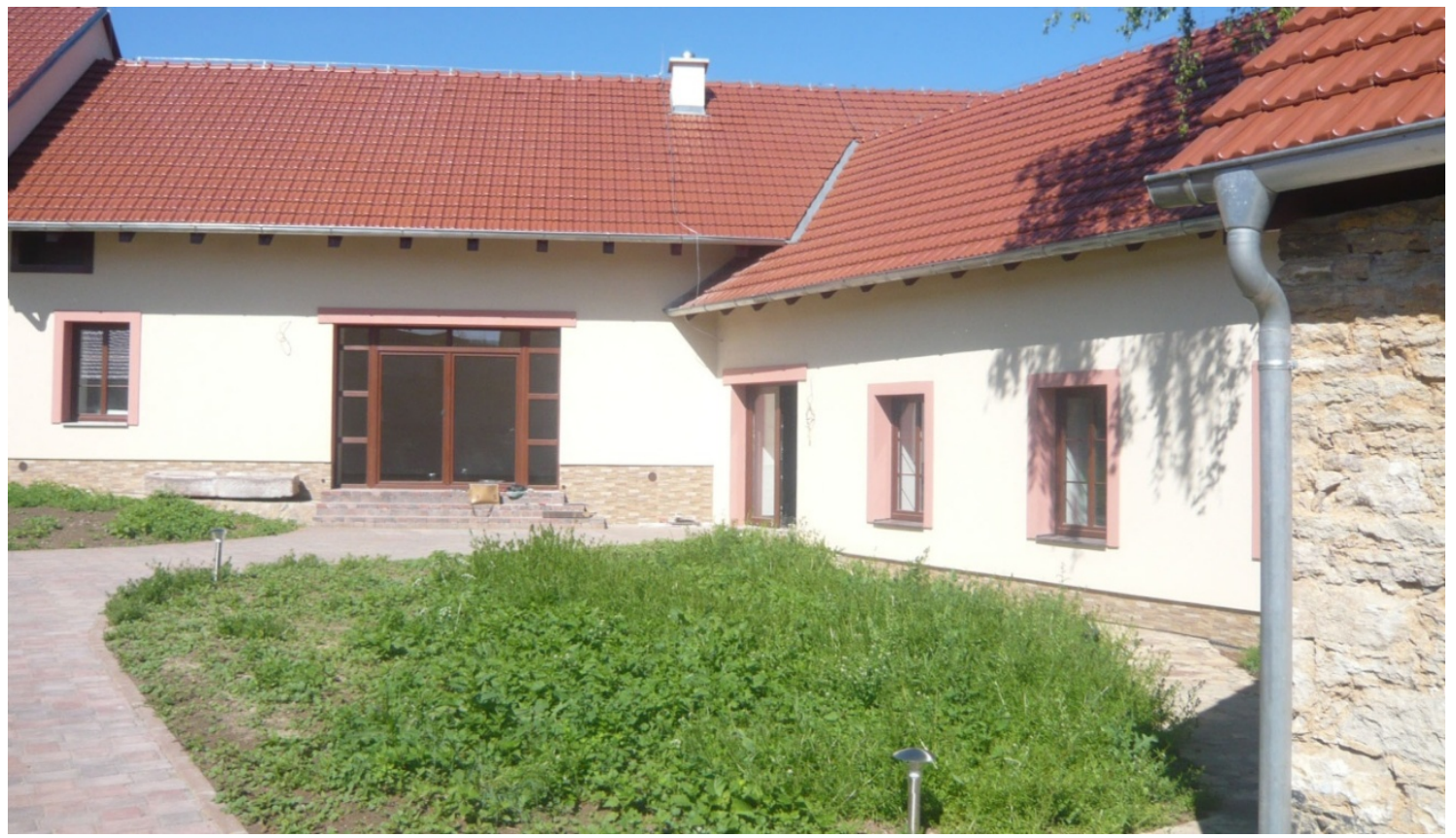

Fig. 6 Farm in Koneprusy, adaptation of farm building for family housing by architects J. Sykora and Z. Peskova, 2009-2011 (photo by author).

the original historic centre. Today, the agricultural function has almost disappeared in the centre and its mass production should not disturb the character of the village core. Residential and civic facilities should be strengthened even in different mixed functions. Unused farm buildings can be utilized to provide space to strengthen these components of functional use in the historic centre. 


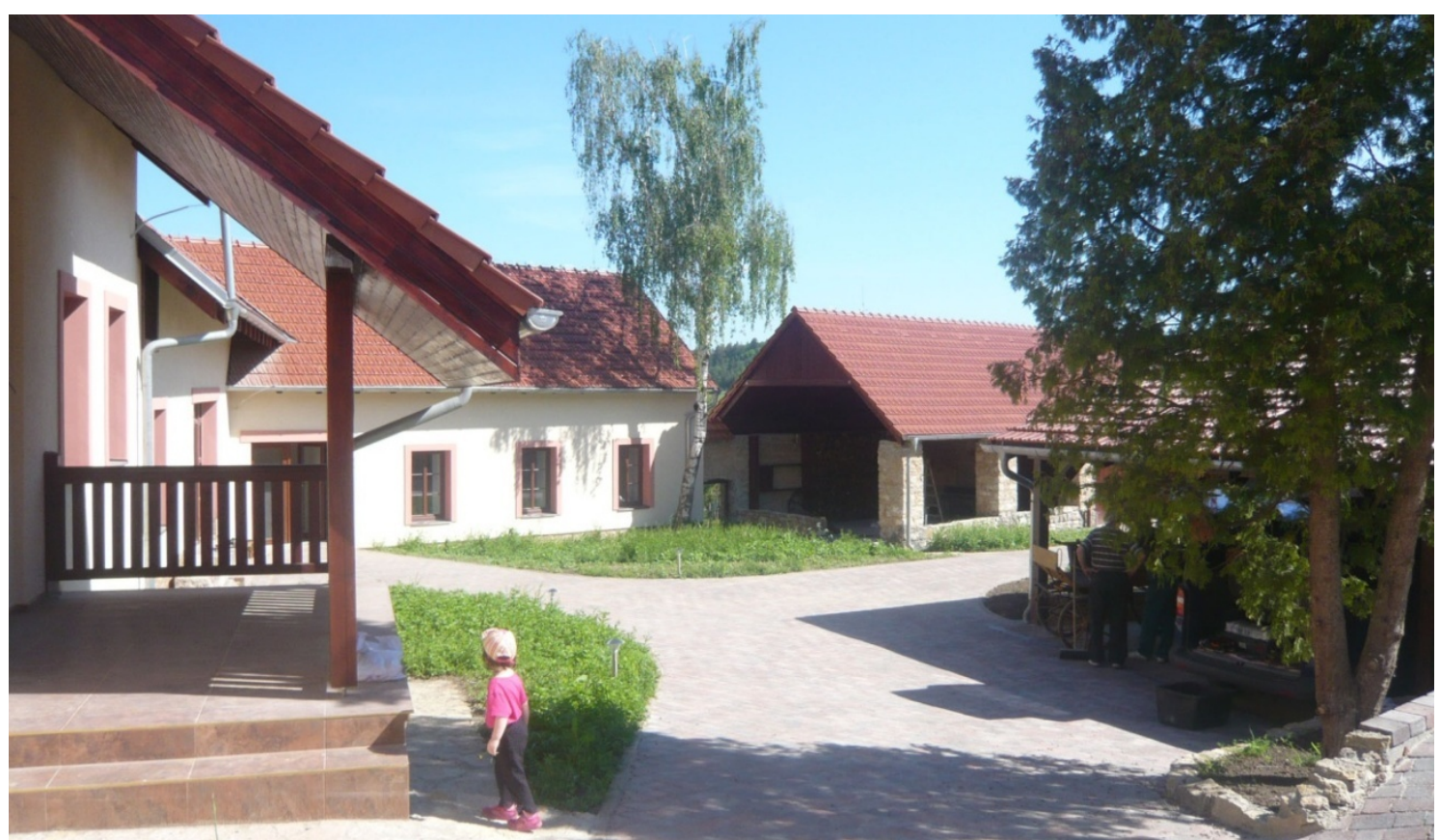

Fig. 7 Farm in Koneprusy, adaptation of farm building for family housing-new farmyard by architects J. Sykora and Z. Peskova, 2009-2011 (photo by author).

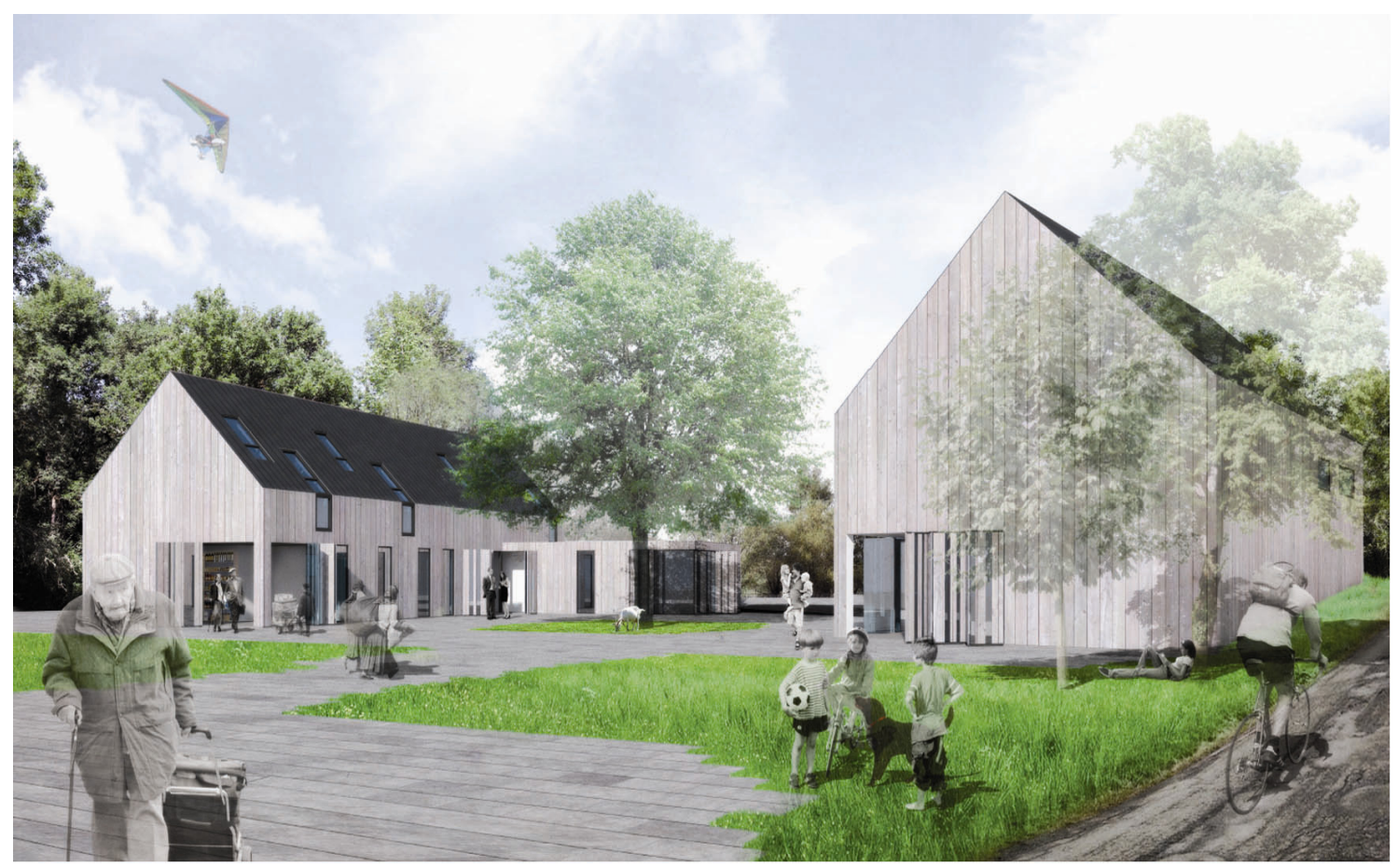

Fig. 8 Application example of traditional Czech homestead and contemporary architectural detail (Hybralec village center, student design, author S. Tomasova, supervisor Z. Peskova, B. Kosatka and J. Kaspar, 2012).

The historic village core in present Czech urban design practice is solved just in one residential mixed function area with islands of civic facilities (school, municipal office, church with rectory and a pub). Small villages require more extensive detail. The area of private gardens and orchards very often determines rural characteristic features. Therefore, they should be mentioned in the new urban function layout. Public 


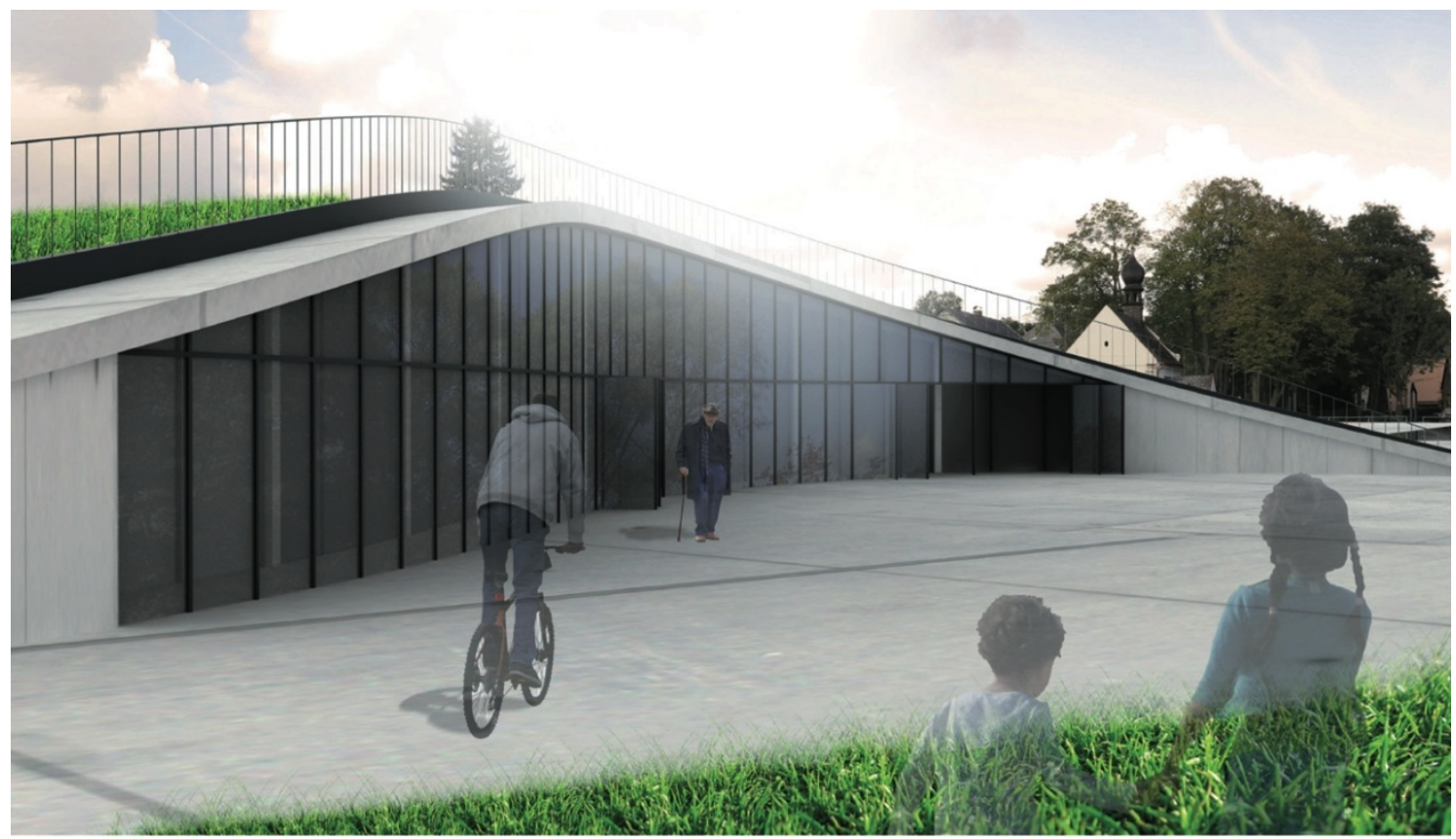

Fig. 9 Application example of modern design (Hybralec village center, student design, author J. Vild, supervisor Z. Peskova, B. Kosatka and J. Kaspar, 2012).

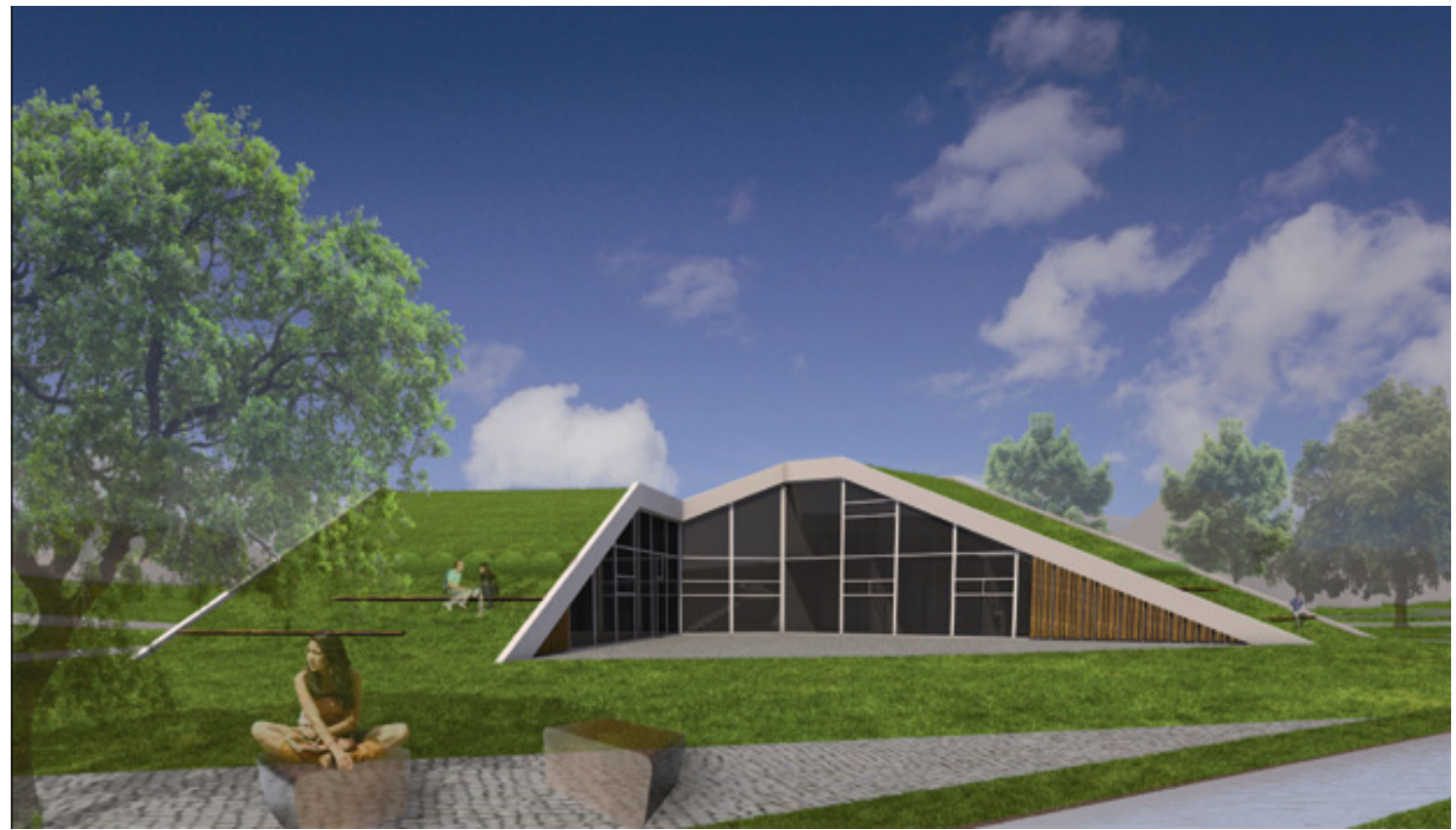

Fig. 10 Application example of modern design (Hybralec village center, student design, author B. Olexova, supervisor Z. Peskova, B. Kosatka and J. Kaspar, 2012).

space also plays a very important role in the analyses. Demarcation, assessment of positives and negatives including traffic imperfections, which attribute to the structure, are not originally designed for motor traffic and are a very frequent phenomenon [12]. Dwelling areas as such should also admit other functions, especially in connection with small scale farming (cultivation of fruit and vegetable, breeding small animals). Pure residential areas, typical for cities, are not very good here. Therefore, Czech urban plans commonly use the term rural dwelling type. 


\section{Conclusions}

Even though the historic core of the village is viewed as dilapidated and already considered as obsolete urban structures which are gradually being abandoned, these places and their building stock offer a great potential for development within the current borders of the built up areas.

The main solutions were traced in many theoretical and practical examples. One aspect is urban planning. The smaller scale of the historic village core should be reflected in the main urban plan design. The approach commonly used in cities is not suitable for rural spaces. The design of new functional layouts and spatial regulations should be more in depth. For example, private greenery, usually not considered separately in the map of functional city layouts, should be determined very carefully in the map of a functional village layout. Just the areas of gardens and orchards are significant for rural space. Regarding the main function suitable for a village centre, agriculture has nearly disappeared. So the new function should be found for the original agriculture building stock (barns, granaries, stables and sheds).

The easiest point to implement is a non-invasive design which involves leaving the land allotment and the historic urban structure in its current state. Vacant lots, ruins and demolished structures are identified during the processing of urban planning documentation on their parcels so that they are designated as new functional plots. Regulations then outline the character of the new buildings. Defined stages can clarify which will be the first sections to be developed and after what may be extended to the current level of the built-up area of the village centre.

In the aspect of ownership, an invasive design is much more problematic. The original large parcels are divided into smaller sizes suitable for current non agricultural needs. This solution for the whole village centre is still theoretic enough, however, it is more practical to divide individual parcels, especially in the case of larger farms.
In the viewpoint of architecture design, this method of reconstruction can be successfully used, especially in the refurbishment of old barns which provide interesting potential thanks to the larger-span structures. Refurbishment of stables is more problematic, where there is usually a high quotient of salt in the structures. Regarding newly built houses, there are two main ways, either a conflict free way of traditional volume with modern details or the arduous way of totally modern design. Architects should be submissive in rural area, sensitive to the context of locality and to details.

A suitable urban plan and architectural interventions can adapt very well in historical structures into the needs of contemporary people while maintaining the continuity of the development of the village, including its historical urban and architectural traces.

\section{Acknowledgments}

This paper was supported by SGS12/018/OHK1/1T/11, the identification of urban and architectural values in the main public space of a village.

\section{References}

[1] A. Viklický, Urbanistické Problem Vesnice a Zemědělské Krajiny (Urban Problems of Village and County Side), Výzkumný Ústav Výstavby Architektury-Skupina Územního Plánování v Brně, Brno, 1953. (in Czech)

[2] J. Škabrada, S. Voděra, Vesnické Stavby a Jejich Úprava, (Rural Buildings and Their Refurbishment), Státní Zemědělské Nakladatelství v Praze, Prague, 1975. (in Czech)

[3] Colective of Authors, Transformations in Twentieth-Century Architecture, Gasset, Praha, 2012. (in Czech)

[4] Nature Conservation Agency of the Czech Republic [Online], www.old.ochranaprirody.cz/res/data/116/015674.pdf (accessed Jan. 15, 2013). (in Czech)

[5] I. Čapounová, Venkov a Krajina (Country and Landscape) [Online], 2010, http://www.archiweb.cz/news.php?type=1\& action $=$ show\&id=8867. (in Czech)

[6] Z. Smetánka, Život Středověké Vesnice—Zaniklá Svídna (The Life of a Medieval Village), Academia, Praha, 1988. (in Czech)

[7] Design Clean Energy Cities (MIT - City Design and Development) [Online], MIT School of Architecture and 
Planning, 2011, http://sap.mit.edu/resources/portfolio/clean/ (accessed Jan. 15, 2013).

[8] Stavba Pro Venkov '97-'98, MMT ČR, MMR ČR, MŽP ČR, Praha (Colectie of Authors, Building for Countryside '97-'98, MMT CR, MMR CR, MZP CR), Prague, 1998.(in Czech)

[9] Z. Pešková, Center of the village Hybralec, in: Člověk, Stavba, Územní Plánování 7 (Human, Building, Urban Planning 7), Czech Technical University in Prague, Prague, 2013. (in Czech)
[10] Pasivní Domy Koberovy (Passive Houses in Koberovy) [Online], Atrea, 2007, http://domy.atrea.cz/cz/pasivni-do my-koberovy. (in Czech)

[11] J. Škabrada, Lidové Stavby-Architektura Českého Venkova, (Folk Architecture-Czech Rural Architecture), Argo, Prague, 1999. (in Czech)

[12] Z. Pešková, J. Sýkora, Hodnocení historického jádra venkovských sídel pro potřeby výuky (Centre of settlements for teaching purposes), Stavební Obzor 6 (2011) 187-191. (in Czech) 